\title{
トンネル近接建物への交通振動の伝搬特性に関する研究 A STUDY ON PROPAGATION PROPERTIES OF TRAFFIC VIBRATION FROM TUNNEL TO NEAR BUILDING
}

\author{
武居＼cjkstart泰*，藤井 光治郎**，伊 積 康 彦*，中井 正 - *** \\ Yasushi TAKEI, Kojiro FUJII, Yasuhiko IZUMI \\ and Shoichi NAKAI
}

\begin{abstract}
In order to predict the level of vibration and structure-borne sound of a building near the underground railway tracks, it is essential to investigate vibration propagation from the ground to the foundation of the building. Therefore, the authors proposed a simple prediction method of vibration propagation from the ground to pile-foundations based on the dynamic-substructure method, which was able to consider the soil-structure-interaction. In the method, input vibration to pile-foundations and response ratio of upper-structures with the dynamic-soil-spring were calculated. We predicted the vibration propagation from the tunnel to the buildings of three types, and confirmed that the predicted results were similar to the measurements.
\end{abstract}

Keywords : traffic vibration, underground railway, tunnel, propagation of vibration, pile foundation, soil-structure interaction 交通振動，地下鉄道，トンネル，振動伝搬，杭基礎，動的相互作用

\section{1. はじめに}

建物が密集している都市部では、既設の建物に近接して鉄道を敷 設したり、既設の鉄道軌道に近接して建物を建設する場合が多く見 られる。特に、地下鉄道の場合、トンネル躯体と建物基礎が数メー トルの距離で接近することがあり、列車走行に伴い発生する振動に よる建物内の体感振動や振動に起因する固体音が問題となる場合が ある。このような振動の伝搬特性は、加振源（車両一軌道系）、発生 源側構造物、地盤、受振側建物の特性と関連した複雑な問題となる ため、建物内の振動を精度よく予測するためには、各伝搬経路にお ける特性を把握する必要がある。特に、地盤から建物基礎への振動 伝搬については、予測を行う上で重要な要素を占めるが、地盤一基 礎連成系の動的相互作用を考慮する必要がある。

耐震構造の分野では、地盤と建物の動的作用問題は古くから研究 が進められ、2000 年に告示化された限界耐力計算法 ${ }^{1)}$ の中にも動的 地盤ばねや基䃈入力動の考え方が導入され、一般建物の設計に動的 相互作用の影響が考慮されるようになってきた。ただし、耐震分野 では、主な対象は周波数が $10 \mathrm{~Hz}$ 程度以下の水平動であり、交通振 動で対象とする高周波数領域の上下動まで含めたものではない。

交通振動に適用できる地盤から建物基礎への簡易な振動伝搬評 価手法として、直接基礎に対しては、地盤振動の位相差を考慮した 入力損失の算定式が山原 ${ }^{2}$ などにより提案され、実測結果との比較 も行われている ${ }^{3)}$ 。深沢ら ${ }^{4)}$ は、地震動の入力損失フィルタを微振 動に適用し直接基礎の水平動の予測を行っている。高木ら ${ }^{5)}$ は、動
的サブストラクチャ法 ${ }^{12)}$ を適用し、布基礎を有する建物の上下振動 予測を行っている。

一方、杭基礎に対しては、汎用的な評価手法として、実測結果を 統計処理する方法が提案されているが 6) 7)、動的相互作用を考慮した 実用的な評価手法は確立されていない。動的相互作用を考慮できる 振動予測手法として、有限要素法等による地盤一建物系モデルの数 值解析手法が適用される場合が多い ${ }^{8)}$ 。筆者らも、実大建物を対象 として二次元有限要素法により振動伝搬解析を行い、実測結果との 比較をしてきたが 9) 10)、杭基礎を二次元でモデル化することの妥当 性について詳細な検討はしていない。三次元解析として、高野ら ${ }^{11)}$ は薄層要素法により地表面点加振時の基礎梁を含めた群杭基礎の入 力損失について検討している。しかし、鉄道振動は対象とする周波 数が地震動より高いため、解析モデルの要素を十分細かく分割する 必要があり、トンネルー地盤一建物系のような複雑なモデルを三次 元で解析することは、モデル化の労力や計算時間等から実用的な手 法とは言えない。

筆者らは、杭基礎への振動伝搬性状を把握するため、比較的規模 の大きいトンネルー地盤一架構系の縮小模型を用いた加振実験を実 施し、動的サブストラクチャ法の考え方に基づき、動的相互作用 (入 力の相互作用と慣性の相互作用）の影響を考慮できる簡易な振動予 測手法を提案し、実験結果との対応が良好であることを示した ${ }^{13)}$ 。 本論文では、トンネルに近接する実大建物を対象として、トンネル、 地表面および建物の振動実測結果を示すとともに、提案した手法に
* (財)鉄道総合技術研究所 主任研究員·工修

** 元(財)鉄道総合技術研究所 主任研究員・工修

*** 千葉大学工学部都市環境システム学科 教授・工博
Senior Researcher, Railway Technical Research Institute, M. Eng.

Former Senior Researcher, Railway Technical Research Institute, M. Eng.

Prof., Dept. of Urban Environment Systems, Faculty of Engineering, Chiba University, Dr. Eng. 

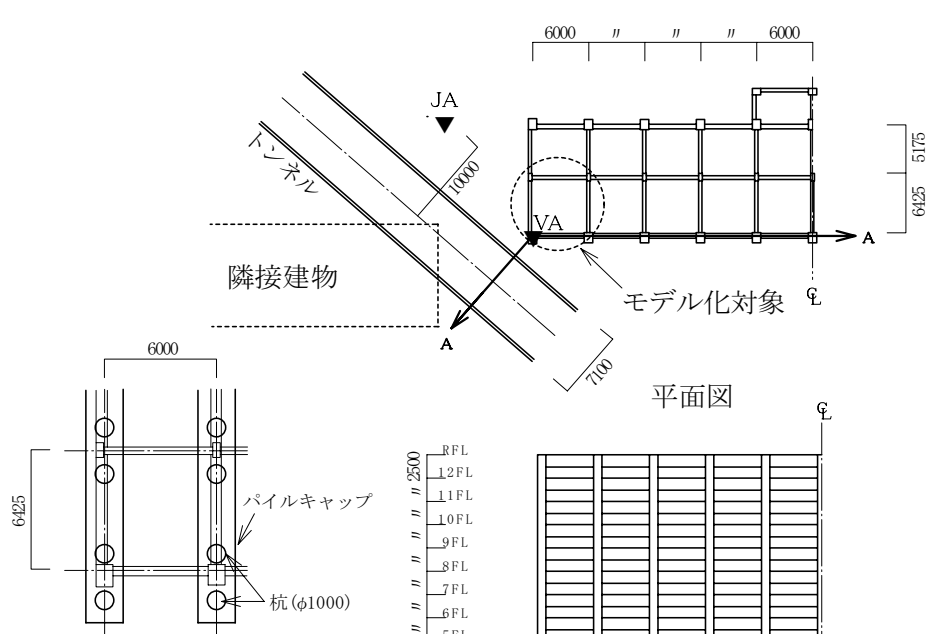

基礎伏図

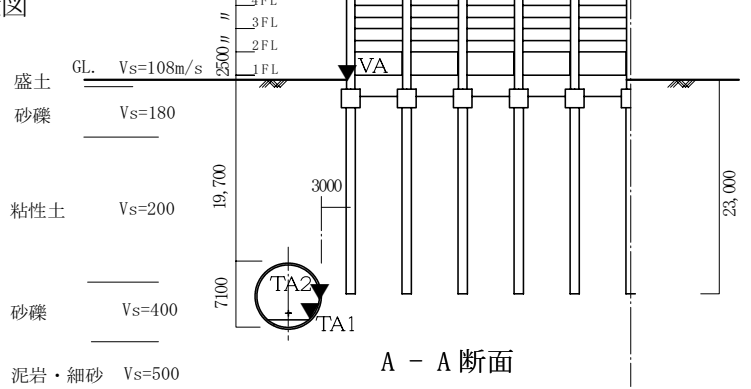

図 1 測定対象（ケースA [A建物 $]$ )

より建物への振動伝搬を予測し、実測結果と比較することにより予 測手法の妥当性について考察する。なお、地下鉄道では、一般的に 上下振動が問題となり、また、環境アセスメントにおいても上下振 動を評価していることなどから、本論では上下振動を対象とする。

\section{2. トンネルー地盤一建物の振動測定}

\section{1 測定概要}

\section{(1)測定対象}

測定対象はトンネル・地盤・建物条件がそれぞれ異なる 3 地点 (ケ ース $\mathrm{A} \sim \mathrm{C} ）$ とした。建物形状、トンネルと建物の位置関係、地盤 条件および振動測定位置を図 1 3、トンネル形状・土被りなどの諸 元を表 1 に示寸。各ケースとも建物の隅角部近傍にトンネルが斜め 方向に位置している。建設順序はトンネルが建物より後で、軌道側 で防振対策が施されているが、建物側の防振対策は特に施されてい ない。建物は全て杭基礎を有するコンクリート系建物で、用途は集 合住宅である。

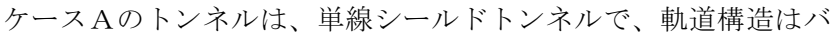
ラスト軌道で防振まくらぎとゴムマットを併設している。地盤は表 層近くに砂砂層がありその下は粘性土で、トンネル中心付近以下が 杭の支持層となる砂碟層である。地盤のせん断波速度 $\left(V_{s}\right)$ は、近隣 敷地で実施した PS 検層結果を参考にした。A建物は、SRC 造の地 上 12 階建てでトンネル側面と杭中心の最小離れは約 $3.0 \mathrm{~m}$ である。 杭基礎は、直径 $1000 \mathrm{~mm}$ 、長さ約 $20 \mathrm{~m}$ の場所打ち RC 杭で、柱 1 本 当たり 2 本の杭で支持している。

ケース B は土被りの大きい単線シールドトンネルで、小型車両用 の小断面トンネルである。地盤は表層に軟弱な粘土層があり、 $\mathrm{GL}-11 \mathrm{~m}$ 以深は $\mathrm{N}$ 值 50 以上の砂質土である。 $V_{s}$ は $\mathrm{N}$ 值より推定し
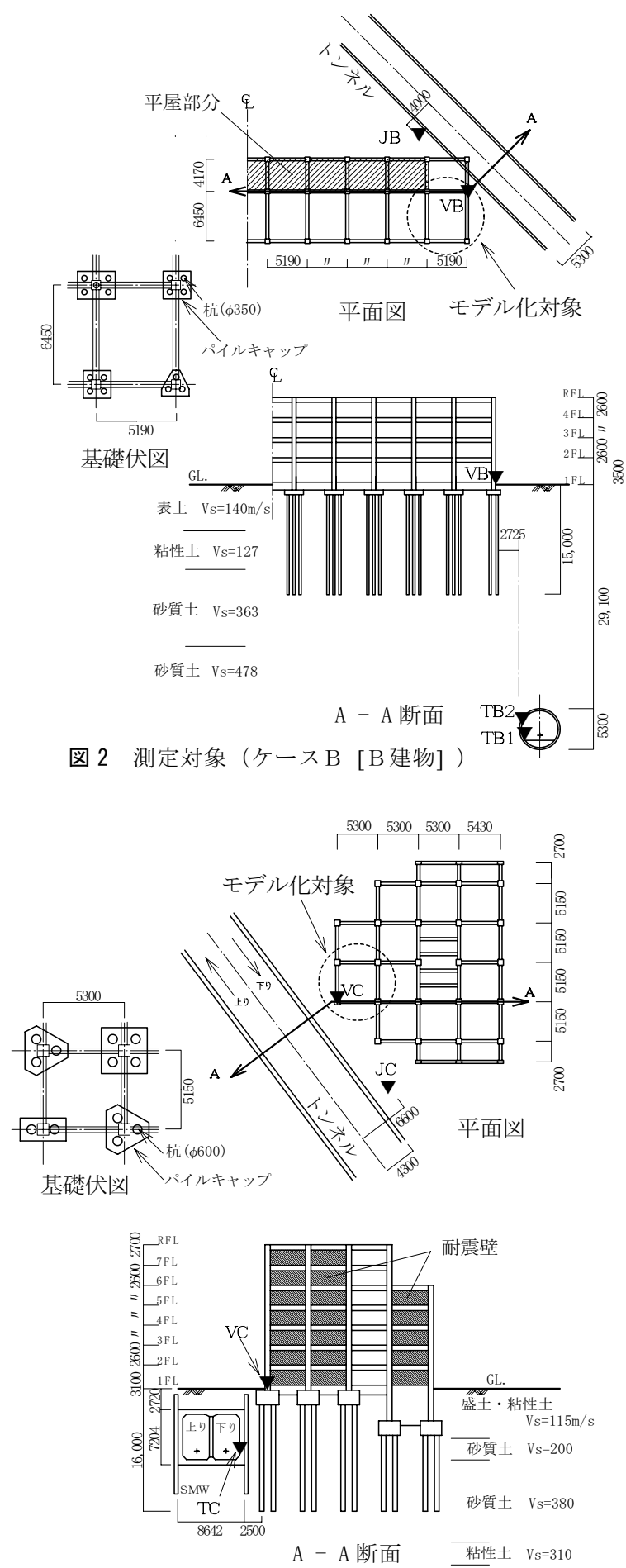

図 3 測定対象（ケースC [C 建物]）＼cjkstart砂質土 $\mathrm{V}_{\mathrm{s}}=380$

表 1 トンネル、軌道構造、列車諸元

\begin{tabular}{|c|c|c|c|}
\hline & ケースA & ケース B & ケースC \\
\hline トンネル & $\begin{array}{l}\text { 単線シールド } \\
\text { (外径 7.1m) }\end{array}$ & $\begin{array}{c}\text { 単線シールド } \\
\text { (外径 } 5.3 \mathrm{~m} \text { ) }\end{array}$ & $\begin{array}{l}\text { 複線開削 } \\
(7.2 \times 8.6 \mathrm{~m})\end{array}$ \\
\hline 土被り & $19.7 \mathrm{~m}$ & $29.1 \mathrm{~m}$ & $2.7 \mathrm{~m}$ \\
\hline 軌道構造 & 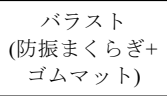 & $\begin{array}{c}\text { コンクリート直結 } \\
\text { (防振まくららぎ) }\end{array}$ & $\begin{array}{l}\text { コイルば叔 } \\
\text { フローティング }\end{array}$ \\
\hline 車両諸元 & $\begin{array}{l}20 \mathrm{~m} / \text { 両 } \\
10 \text { 両編成 }\end{array}$ & $\begin{array}{l}16 \mathrm{~m} / \text { 両 } \\
8 \text { 両編成 }\end{array}$ & $\begin{array}{l}20 \mathrm{~m} / \text { 両 } \\
6 \text { 両編成 }\end{array}$ \\
\hline 運転速度 & $58 \mathrm{~km} / \mathrm{h}$ & $40 \mathrm{~km} / \mathrm{h}$ & $80 \mathrm{~km} / \mathrm{h}$ \\
\hline
\end{tabular}



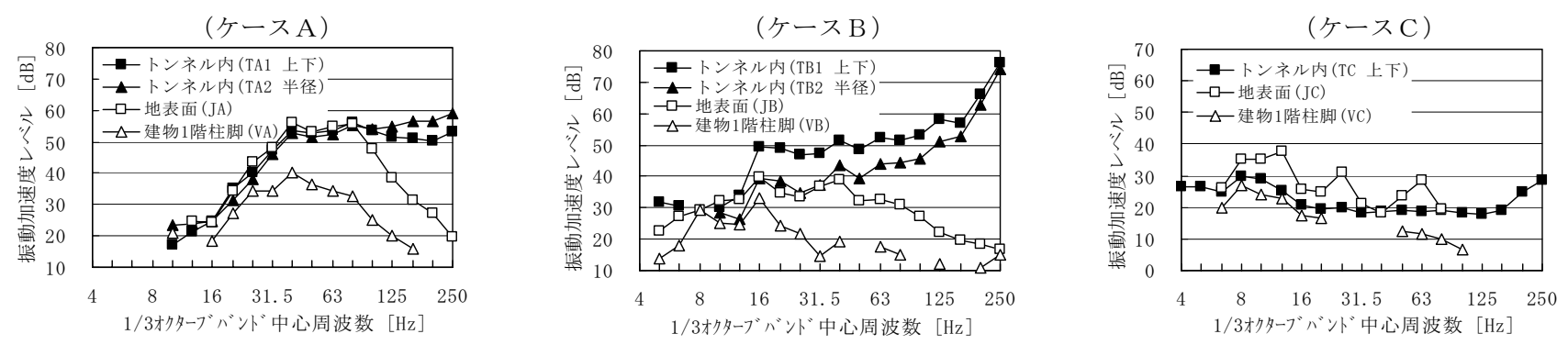

図 4 振動加速度レベル（実測結果）

た ${ }^{14)}$ 。軌道構造は、コンクリート直結軌道で防振まくらぎが設置さ れている。 $\mathrm{B}$ 建物は、 $\mathrm{RC}$ 造の地上 4 階建て (一部平屋) で、トン ネルの一部が建物の下に重なっている。杭基礎は、直径 $350 \mathrm{~mm}$ 、長 さ約 $13 \mathrm{~m}$ の $\mathrm{RC}$ 既製杭で、柱 1 本当たり $3 \sim 5$ 本の杭で支持してい る。

ケース C は土被りの浅い開削工法の複線トンネル（ボックスカル バート) である。トンネル側面には土留壁としてソイルセメント連 続壁（SMW）が設置されている。軌道構造は、支持支承にコイルば 永（設計用上下固有振動数:7.6Hz）を使用したフローティングスラ ブ軌道である ${ }^{15)}$ 。地盤はトンネル底面までが軟弱な粘性土と砂質土 で、GL-9m 以深に $\mathrm{N}$ 值 50 以上の砂質土がある。 $V_{s}$ は $\mathrm{N}$ 值より推定 した ${ }^{14)}$ 。C 建物は、 $\mathrm{RC}$ 造の地上 7 階建て（一部地下 1 階）でトン ネル側壁と杭中心の最小離れは約 $2.5 \mathrm{~m}$ である。杭基礎は、直径 $600 \mathrm{~mm}$ 、長さ約 $14 \mathrm{~m}$ の PHC 杭で、柱 1 本当たり 2 4 本の杭で支持 している。

(2)測定方法

振動の測定には圧電型加速度ピックアップを用い、上下方向（ト ンネル内は側壁下部の上下方向と側壁アーチ部の半径方向）の振動 加速度波形をデータレコーダに収録し、計測した波形を周波数分析 し 1/3 オクターブバンド毎の振動加速度レベル值にした（時定数 1 秒、バンドマックス值)。列車速度等の条件が概初等しい数列車の 值を算術平均して代表値とした。対象周波数範囲は $4 \sim 250 \mathrm{~Hz}$ とし た。なお、暗振動レベルに近いデータについては暗振動レベルに応 じて補正したが（JIS Z8735 を準用）、暗振動レベルとの差が $3 \mathrm{~dB}$ 以 下のデータについてはデータの信頼性を考慮して削除した。

測定位置は、トンネル内側壁、地盤（地表面）およびトンネルに 近接した建物 1 階柱脚とした。地表面の測定点は、建物の影響を受 けないように、トンネルからの距離が測定柱脚位置と概称同じで、 かつ可能な範囲で建物から離れた地表面上とした。ケース C はトン ネル内と地盤・建物を同時測定した。ケース A、Bについてはトン ネル内と地盤・建物は別時刻に測定したが、両ケースとも地表面の 代表基準点における振動は概放等しいことを確認している。

\section{2 測定結果}

(1) トンネル・地盤・建物の振動性状

各ケースのトンネル内、地表面および建物 1 階柱脚における振動 加速度レベルの周波数特性を図 4 に示す。トンネル内の振動は、ト ンネル形状や軌道構造等の違いにより各ケースで異なった。ケース Aでは、31.5〜200Hz にかけてほぼ平坦なピークを示した。ケース Bでは $125 \mathrm{~Hz}$ 以上で高周波数ほど大きくなったが、これは小型車両 であることが原因の一つとして考えられ、他の測定事例 ${ }^{16)} て ゙ も$ 同様

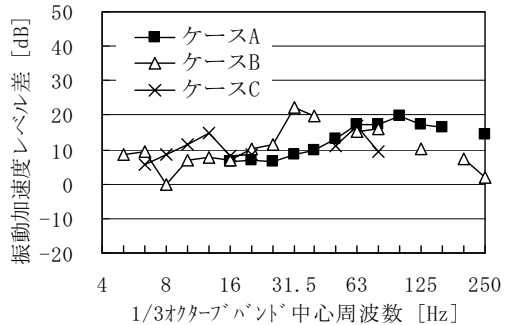

図 51 階柱脚に対する地表面の振動加速度レベル差(振動伝搬量)

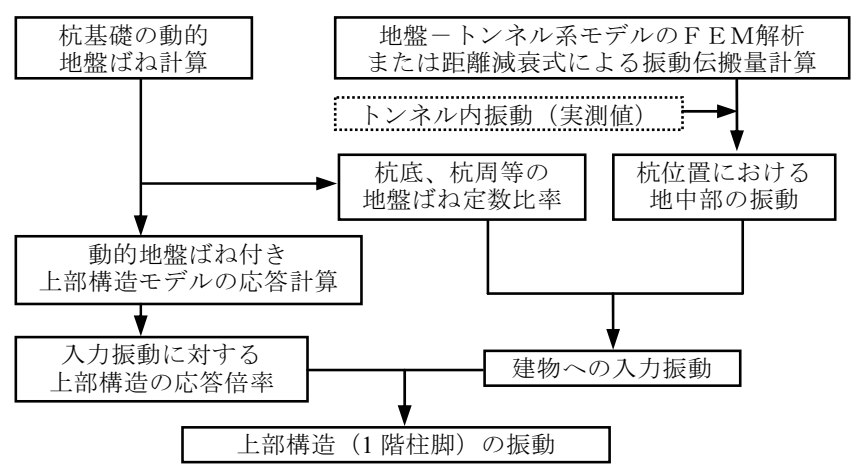

図 6 振動伝搬予測フロー

の傾向が報告されている。ケース Cでは防振効果の高い軌道が用い られているため振動が小さく、周波数特性は $8 \sim 10 \mathrm{~Hz}$ 付近の軌道構 造の共振と思われる小さなピークを除き $160 \mathrm{~Hz}$ までほぼ平坦であっ た。地表面振動は、ケース Aでは $80 \mathrm{~Hz}$ 以上で、ケース Bでは $16 \mathrm{~Hz}$ 以上でトンネル内（上下方向）に対し大きく減衰した。ケースCで はトンネル内（上下方向）と比心゙周波数によっては増幅した。これ は、トンネル躯体の振動や施工時に表層地盤が乱された影響などが 考えられる。建物 1 階柱脚では、各ケースともトンネル内や地表面 に対し減衰し、高周波数ほじ顕著であった。

(2)地表面と建物基礎の振動比較

地表面と建物基礎の振動性状を比較するため、建物 1 階柱脚に対 する地表面の振動加速度レベル差（振動伝搬量）を図 5 に示す。振 動伝搬量は各ケースとも概衫同じ傾向を示し、100Hz 程度までは高 周波数になるほど大きくなった。

\section{3.トンネルから建物への振動伝搬予測}

\section{1 予測手法の概要}

建物内に伝搬する鉄道振動を予測する上で、地盤から建物基礎一 の振動伝搬は重要な要素を占める。そこで、地盤と建物の動的相互 作用を考慮した杭基礎への振動伝搬を予測する簡易な手法を構築す るため、前節に示した実大建物を対象として検討した。 
振動伝搬予測フローを図 6 に示す。動的サブストラクチャ法の考 え方に基づき、建物を杭頭位置で仮想的に切断し、杭頭位置の振動 （建物への入力振動）と動的地盤ばねを取り付けた上部構造モデル の応答倍率から、建物の振動を予測する。なお、本検討では、建物 振動の予測位置はトンネルに近接する 1 階柱脚とし、対象上限周波 数は $125 \mathrm{~Hz}$ とする。

杭の動的地盤ばねについては、地盤や杭の条件から計算式 ${ }^{17)}$ (付 録 1 参照）により簡便に求めることができる（以下、簡便法）。各建 物とも基礎は全て群杭であることから、ば社定数（実部）の算定で は群杭係数を考慮し、減衰係数（虚部）の算定では図 7 に示すよう に杭で囲まれる範囲を杭基礎底面とみなして等価基礎半径を求める。 なお、杭以外からの振動伝搬として、基礎スラブ部分（以下、パイ ルキャップ）の底面（杭で囲まれた範囲以外）からの伝搬を考慮し、 地表面直接基礎と仮定して DGC 理論 ${ }^{18)}$ とより動的地盤ばねを算定 し、杭の地盤ばねに付加する。

建物への入力振動については、杭の鉛直剛性が周辺地盤に対し相 対的に十分大きいことから、杭先端と杭周の動的地盤ばねのばね定 数に比例して地盤から杭一振動が入力されると仮定して、(1)式に示 すように地中部の振動加速度を加重平均して求める。このような入 力の相互作用の考え方は、限界耐力計算法 ${ }^{1}$ におおる地下部分が存 在寸る場合の建物への入力地震動の算定手法と同様である。杭位置 における地中部振動（ $\left.A_{S b} 、 A_{S i} 、 A_{S p}\right)$ は、地盤一トンネル系モデル の 2 次元有限要素法 (F E M ) 解析により求める。トンネルから地 中部・地表面一の振動伝搬予測において、2 次元 F E M 解析が有効 であることは、実測結果との比較から確認している ${ }^{19)}$ 。また、シー ルドトンネルについては、トンネルから地盤への周波数帯毎の減衰 を表す算定式（以下、距離減衰式）が提案されているため ${ }^{20)}($ (付録 2 参照)、ケース A、Bにおいて数值解析を用いない略算手法として 適用し、地中部振動を求める。

$$
\begin{aligned}
& A_{S}(f)=20 \cdot \log \left(\alpha \cdot 10^{A_{S b}(f) / 20}+\sum_{i=1}^{n} \beta_{i} \cdot 10^{A_{S i}(f) / 20}+\gamma \cdot 10^{A_{S p}(f) / 20}\right) \quad \cdots(1) \\
& A_{S b}(f)=H_{S b}(f)+A_{M}(f) \\
& A_{S i}(f)=H_{S i}(f)+A_{M}(f) \\
& A_{S p}(f)=H_{S p}(f)+A_{M}(f)
\end{aligned}
$$

振動伝搬量 $(\mathrm{dB})$

$A_{M}(f)$ : トンネル内の振動加速度レベル[実測值] (dB)

$f: 1 / 3$ オクターブバンド中心周波数 $(\mathrm{Hz})$

$\alpha:$ 杭先端の地盤ば祮定数比率 $\left(=k_{b} /\left(k_{b}+\sum^{n} k_{i}+k_{p}\right)\right)$

$\beta_{i}$ : 杭周 $(i$ 層 $)$ の地盤ばね定数比率 $\left(=k_{i} /\left(k_{b}+\sum_{i=1}^{n} k_{i}+k_{p}\right)\right)$

$\gamma:$ パイルキャップ底面の地盤ば衩定数比率 $\left(\stackrel{i=1}{=} k_{p} /\left(k_{b}+\sum_{i=1}^{n} k_{i}+k_{p}\right)\right)$

$k_{b}:$ 杭先端の動的地盤ばねのば站定数

$k_{i}:$ 杭周 $(i$ 層 $)$ の動的地盤ばねのばね定数

$k_{p}$ : パイルキャップ底面（杭範囲以外）の動的地盤ばねのば放定数

次に、地盤ばね一上部構造系の慣性の相互作用を考慮するため、

1 階の質点に杭の動的地盤ばね（ばね要素と減衰要素）を取り付け
た質点モデルの動的解析により入力振動に対する建物の応答倍率を 求める。動的地盤ばねの付加質量は全質量に対して小さいため無視 するが、 1 階の質点にはパイルキャップ・基礎梁の質量を考慮する。 上部構造のモデル化範囲はトンネルに最も近接する 1 スパンとし (図 1 参照)、各階の質量を一つの質点に集約し、各質点間を繋ぐ上 下ばねは、柱と壁の鉛直剛性（柱・壁の断面積 $\times$ 弾性係数 /階高） から求める。地盤ばね下端をインパルス加振したときの 1 階質点の 応答を時刻歴応答解析により求め、応答結果を周波数变換して入力 に対する応答倍率を求める。減衰はレーリー型とし、減衰定数は対 象周波数範囲 $(5 \sim 160 \mathrm{~Hz})$ で約 $2 \%$ になるように設定する。

また、床スラブの上下振動の影響を検討するため、Rayleigh-Ritz 法 ${ }^{21)}$ を適用して矩形スラブ板モデルの 1 次モードの固有振動数と有 効質量を求め、そのモードにおけるばね定数を算出し、各階質点に 床スラブの振動系を表す 1 質点のばね一質量モデルを付加する。

建物への入力振動と建物の応答倍率から、建物の振動を(2)式よ り求める。

$$
A_{F}(f)=A_{S}(f)+H_{F}(f) \quad \cdots(2)
$$

$A_{F}(f)$ : 建物（1 階柱脚）の振動加速度レベル $(\mathrm{dB})$

$H_{F}(f)$ : 入力振動に対する建物の応答倍率 $(\mathrm{dB})$

\section{2 A 建物の振動予測}

前節に示した手法により、A建物の振動予測を行った結果を以下 に示す。

(1)動的地盤ばね

地盤および杭基礎の諸元から上下方向の動的地盤ばねを簡便法 により求めた結果、パイルキャップ底面を含めた 1 基礎当たり（杭 2 本）のばね定数は $2.5 \times 10^{6} \mathrm{kN} / \mathrm{m}$ 、減衰係数は $1.1 \times 10^{4} \mathrm{kN} \cdot \mathrm{s} / \mathrm{m}$ とな った。比較として、杭をビーム要素、パイルキャップをソリッド要 素、地盤を薄層要素とした地盤一杭系モデルの動的解析（以下、詳 細法) を行い、パイルキャップ上面中央部を上下単位力で加振した ときのパイルキャップの上下方向の応答変位から動的地盤ばねを求 めた結果を、簡便法の結果と併せて図 8 に示す。動的地盤ばねの実 部は、付加質量 $\left(4.5 \times 10^{4} \mathrm{~kg}\right)$ の影響のため周波数が高くなるほど 小さくなったが、静的ばね定数（周波数 $0 \mathrm{~Hz}$ 時）は $3.3 \times 10^{6} \mathrm{kN} / \mathrm{m}$ と なり、簡便法の結果と概㸚対応した。虚部については周波数が高い ほど大きくなり、その傾き（減衰係数）は $2.1 \times 10^{4} \mathrm{kN} \cdot \mathrm{s} / \mathrm{m}$ となり簡 便法に対し 2 倍程度大きくなった。この原因として、詳細法では埋

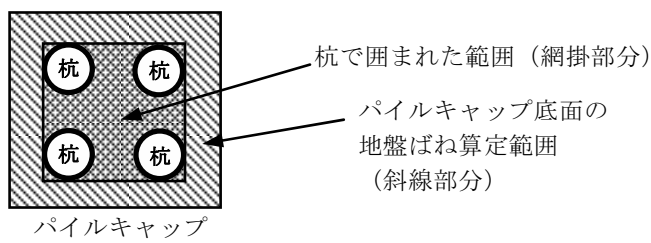

図 7 簡便法による動的地盤ばね算定時の範囲
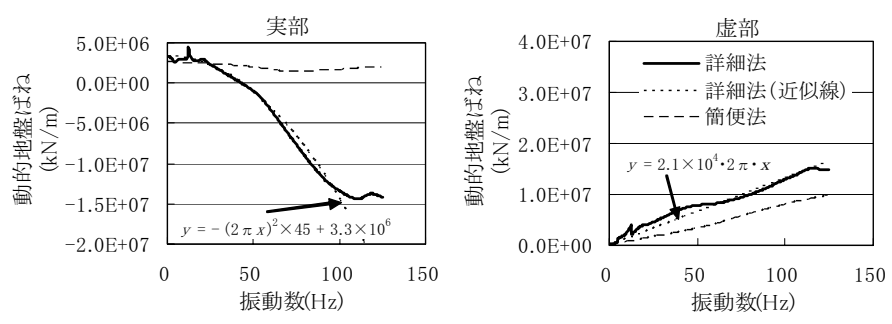

図 8 簡便法と詳細法による動的地盤ばね（ケース A ) 


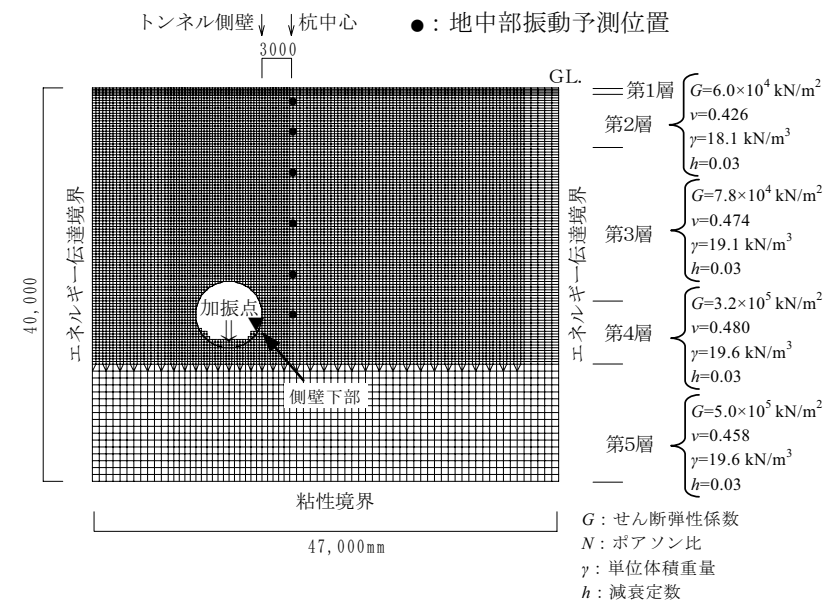

図 9 トンネルー地盤系の 2 次元 F E Mモデル（ケース A）

戻し土となるパイルキャップ側面の物性值を原地盤の值を用いて解 析しているが、簡便法ではパイルキャップ側面を無視して求めてい ることなどが考えられる。なお、減衰係数が建物の応答倍率に与え る影響については、本節(3)で検討する。

\section{(2)入力振動}

トンネルー地盤系の 2 次元 F E Mモデル（図 9）の点加振解析に より、トンネル側壁下部から地中部への振動伝搬量を求めた。振動 伝搬量とトンネル側壁下部における実測值から求めたトンネルに最 も近い杭位置における深さ方向の地中部の振動加速度レベルを図 10(a)に示す。杭底位置の振動は、トンネルとの位置関係等の影響に より、杭底上方の地盤より特に大きくなった。簡便法により求めた 杭先端と杭周の地盤ば福定数およびその比率を表 2 に示す。杭周に ついては、約 $5 \mathrm{~m}$ 毎に分割した。各ばね定数の比率により地中部の 振動加速度を加重平均して求めた振動加速度レベルを同図中に示寸。 また、距離減衰式により求めた地中部振動とその加重平均值を図 10 (b)に示すが、距離減衰式では $63 \mathrm{~Hz}$ 以上で杭底位置の振動は F E $\mathrm{M}$ 結果より小さくなり、加重平均值も $63 \mathrm{~Hz}$ 以上でやや小さくなっ た。なお、参考として地表面の振動について、F E Mおよび距離減 衰式による解析值と実測值の比較を図 11 に示すが、F E M は実測值 にほぼ対応したのに対し、距離減衰式は実測值に対し周波数によっ ては $10 \mathrm{~dB}$ 程度小さくなった。

本手法では、杭の鉛直剛性が周辺地盤に対し十分大きいことを前 提にしているが、実際には杭は剛体ではない。この影響を確認する ため、地盤を薄層要素、杭（杭長 $22 \mathrm{~m} ）$ をビーム要素でモデル化し た単純な地盤一単杭系の点加振解析により、杭径 $1 \mathrm{~m}$ と $2 \mathrm{~m}$ の場合 について検討した。A建物の杭基礎は群杭（杭径 $1 \mathrm{~m} \times 2$ 本）である ため、群杭と等価な断面積を有する単杭に換算すると杭径は $1.4 \mathrm{~m}$ (杭体軸剛性: $1.55 \times 10^{6} \mathrm{kN} / \mathrm{m}$ ) に相当寸る。地中部（杭底から水平 $6.5 \mathrm{~m}$ 離れ）を点加振したときの加振点から杭頭への振動伝搬量と、 杭を取り除いた地盤モデルによる地中部の振動伝搬量の加重平均を 図 12 に示寸。単杭の解析結果のほうが地盤の加重平均に対し高周波 数範囲で杭径 $2 \mathrm{~m}$ の場合最大 $5 \mathrm{~dB}$ 程度、 $1 \mathrm{~m}$ の場合最大 $10 \mathrm{~dB}$ 程度小 さくなったが、この主な原因として、杭が完全な剛体ではないため 杭頭では振動の小さい地表面付近の地盤の影響を受けたことが考え られる。以上より、本例では入力振動をやや過大評価する可能性が あるが、実用上許容できる誤差であると考える。ただし、杭の軸剛
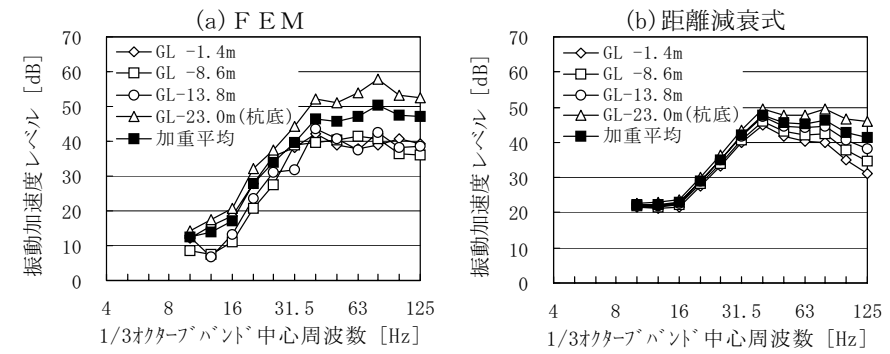

図 10 地中部の振動加速度レベル（ケース A )

表 2 地盤ばね定数と比率（ケースA）

\begin{tabular}{|l|c|c|}
\hline \multicolumn{1}{|c|}{ 部位 } & $\begin{array}{c}\text { 地盤ばね定数 } \\
(\mathrm{kN} / \mathrm{m})\end{array}$ & 比率 \\
\hline パイルキャップ ${ }^{* 2}$ & $2.33 \times 10^{5}$ & 0.093 \\
\hline 杭周(GL-2.8〜-6.0m) & $2.04 \times 10^{5}$ & 0.082 \\
\hline 杭周 $(-6.0 \sim-11.2 \mathrm{~m})$ & $4.32 \times 10^{5}$ & 0.173 \\
\hline 杭周 $(-11.2 \sim-16.4 \mathrm{~m})$ & $4.32 \times 10^{5}$ & 0.173 \\
\hline 杭周 $(-16.4 \sim-21.6 \mathrm{~m})$ & $4.32 \times 10^{5}$ & 0.173 \\
\hline 杭底 & $7.70 \times 10^{5}$ & 0.308 \\
\hline 合計 & $2.50 \times 10^{6}$ & 1.0 \\
\hline
\end{tabular}

*1：1 基礎当たり（杭 2 本分）の值

*2：底面（杭で囲まれた範囲を除く）のみ考慮

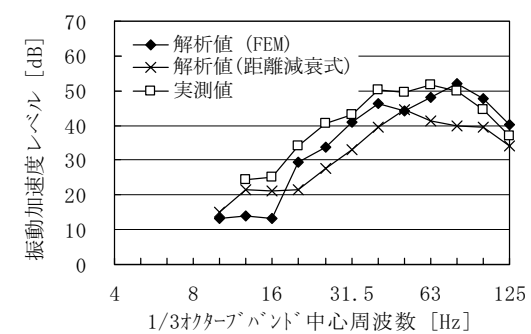

図 11 地表面振動の解析值と実測值の比較（ケースA）
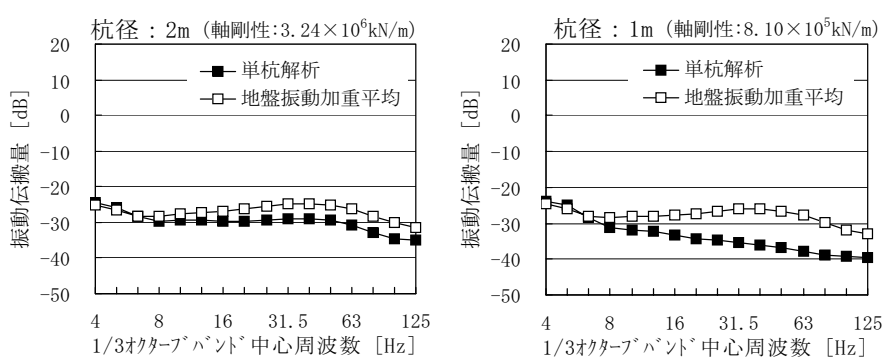

図 12 単杭解析の加振点から杭頭への振動伝搬量と 地中部の振動伝搬量の加重平均の比較

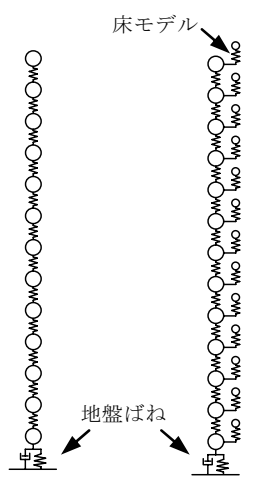

床モデルなし＼cjkstart床モデルあり

図 13 上部構造の質点モデル

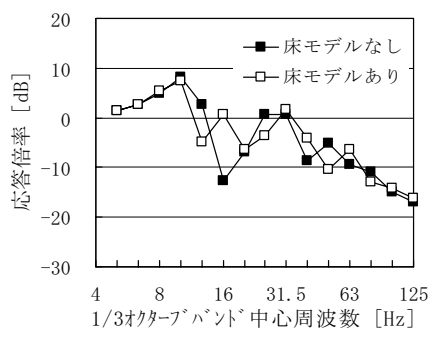

図 14 入力振動に対する 1 階柱脚 の応答倍率 (ケース A) 
性がさらに小さい場合や杭長範囲で地中部の振動差が大きい場合に は、入力振動の誤差がより大きくなる可能性がある。

(3)建物の振動モードと応答倍率

簡便法により求めた地盤ば叔を取り付けた上部構造の質点モデ ル（図 13）の固有值解析により、主要モードの固有振動数および有 効質量比を求めた結果を表 3 に示す。床モデルの有無に関わらず、 1 次モードは地盤ばねが伸縮し上部構造の各質点が同位相で振動す るモードとなり、有効質量の大半を占めた。床モデルがない場合に は、 $2 \cdot 3$ 次モードは上部架構が振動するモードとなった。床モデル がある場合には、2 次モードは床振動が卓越するモードとなり、3 次以上は床を含めた上部架構が振動するモードであった。なお、床 モデルのみの 1 次固有振動数は $14.5 \mathrm{~Hz}$ であった。

入力振動に対する 1 階質点の応答倍率を図 14 に示す。 1 次固有振 動数では応答が増幅し、周波数が高くなるほど減衰が大きくなった。 床モデルがない場合には、 $16 \mathrm{~Hz}$ で大きく減衰したが、床モデルがあ る場合には、床スラブの振動の影響により $16 \mathrm{~Hz}$ での減衰が少なく なった。

地盤ばねの減衰係数が応答倍率に与える影響を把握するため、簡 便法で求めた減衰係数とその 2 倍の值を用いた場合について、応答 倍率を比較した結果を図 15 に示す。1次モードの影響が大きいため、 減衰係数を 2 倍にした場合、 1 次固有振動数付近 $(10 \mathrm{~Hz})$ では応答 倍率がやや小さくなったが、高周波数域 $(80 \mathrm{~Hz}$ 以上) では逆に $5 \mathrm{~dB}$ 程度大きくなった。地盤ばねの減衰係数に関しては、特にパイルキ ヤップが大きい場合などでは埋戻し土の物性評価等も含め、さらに 検討する必要がある。

\section{(4)建物（1 階柱脚）の振動予測}

建物への入力振動と上部構造の応答倍率から求めた 1 階柱脚にお ける振動予測結果と実測結果の比較を図 16 に示す。入力振動につい ては、F E Mで求めた場合と距離減衰式で求めた場合、応答倍率計 算については、床モデルを考慮した場合としない場合について、そ れぞれの組み合わせを示している。16Hz 以下では暗振動に近いため 正確な比較はできないが、F E Mの場合 $80 \mathrm{~Hz}$ 以上で解析值がやや 大きくなったことを除き、予測結果と実測結果はよい対応を示した。 F E M と距離減衰式の予測精度の比較は、地盤ばね等に起因する誤 差の影響もあることから一概には言えないが、距離減衰式を用いた

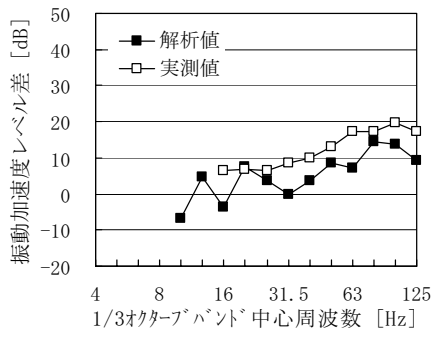

図 171 階柱脚に対する地表面の 振動伝搬量 (ケース $\mathrm{A}$ )

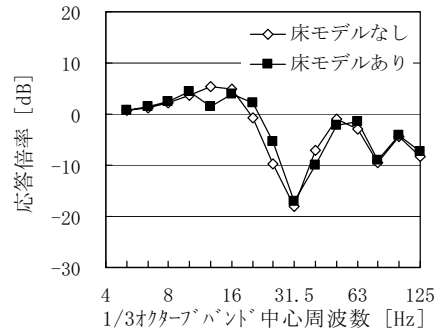

図 19 入力振動に対する 1 階柱 脚の応答倍率 (ケース $\mathrm{B})$
表 5 固有振動数（ケース B ） [Hz]

\begin{tabular}{|l|c|c|c|c|}
\hline & 1 次 & 2 次 & 3 次 & 4 次 \\
\hline 床モデルなし & 15.2 & 55.6 & 96.0 & - \\
& $(0.985)$ & $(0.014)$ & $(0.001)$ & - \\
\hline 床モデルあり & 11.9 & 13.0 & 17.7 & 59.2 \\
& $(0.467)$ & $(0.002)$ & $(0.518)$ & $(0.012)$ \\
\hline
\end{tabular}

( ) 内比有效質量比

表 3 固有振動数（ケース A ） [Hz]

\begin{tabular}{|l|c|c|c|c|}
\hline & 1 次 & 2 次 & 3 次 & 4 次 \\
\hline 床モデルなし & 10.8 & 29.3 & 53.2 & - \\
\hline 床モデルあり & $(0.940)$ & $(0.057)$ & $(0.003)$ & - \\
\hline 参考: 基礎固定 & 10.1 & 14.3 & 17.2 & 32.3 \\
(床モデルなし) & $(0.749)$ & $(0.012)$ & $(0.093)$ & $(0.043)$ \\
\hline
\end{tabular}

( ) 内注有効質量比

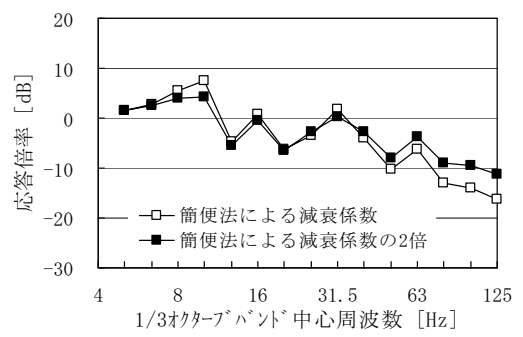

図 15 減衰係数による応答倍率の比較（ケースA）
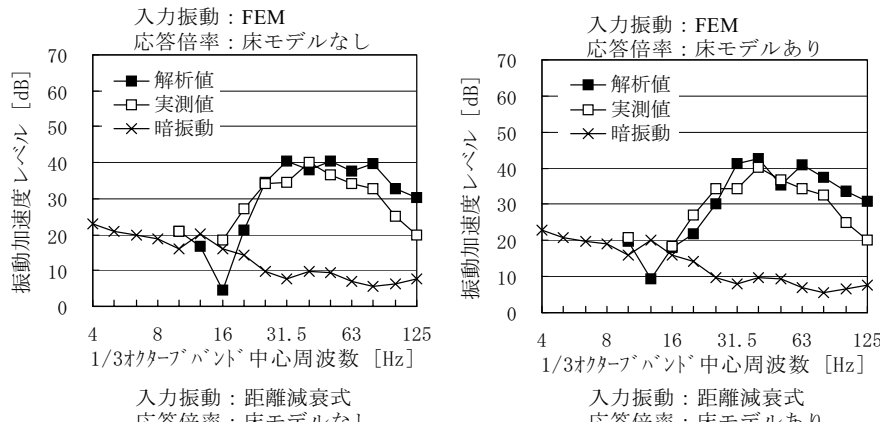

店答倍率 : 床モデルなし
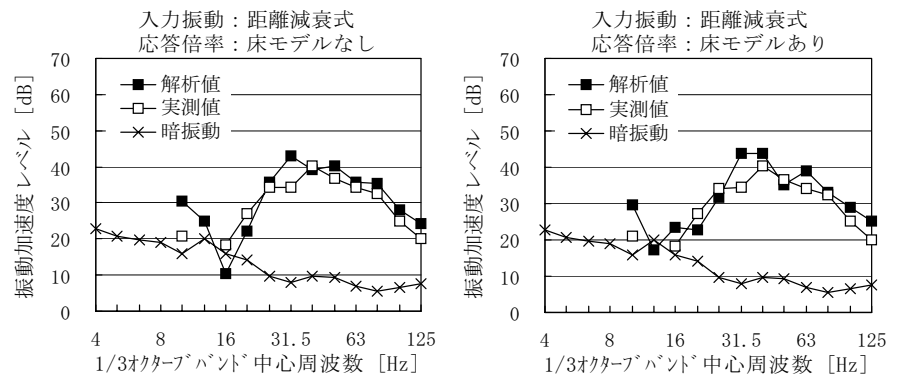

図 161 階柱脚における振動予測結果と実測結果の比較（ケースA）

表 4 地盤ばね定数と比率（ケース B )

\begin{tabular}{|l|c|c|}
\hline \multicolumn{1}{|c|}{ 部位 } & $\begin{array}{c}\text { 地盤ばね定数 } \\
(\mathrm{kN} / \mathrm{m})\end{array}$ & 比率 \\
\hline パイルキャップ ${ }^{* 2}$ & $1.45 \times 10^{5}$ & 0.152 \\
\hline 杭周(GL-0.7〜-6.0m) & $1.85 \times 10^{5}$ & 0.194 \\
\hline 杭周 $(-6.0 \sim-11.0 \mathrm{~m})$ & $3.51 \times 10^{5}$ & 0.369 \\
\hline 杭底 & $2.70 \times 10^{5}$ & 0.284 \\
\hline 合計 & $9.51 \times 10^{5}$ & 1.0 \\
\hline
\end{tabular}

*1： 1 基礎当たり（杭 4 本分）の值

*2：底面（杭で囲まれた範囲を除く）の夕考慮

(a) F E M

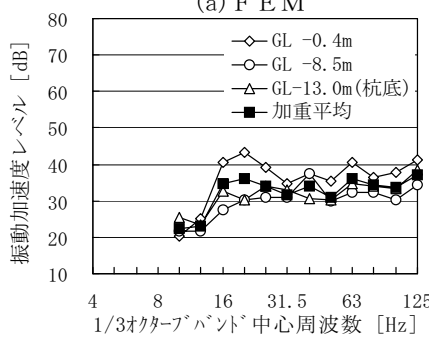

(b) 距離減衰式

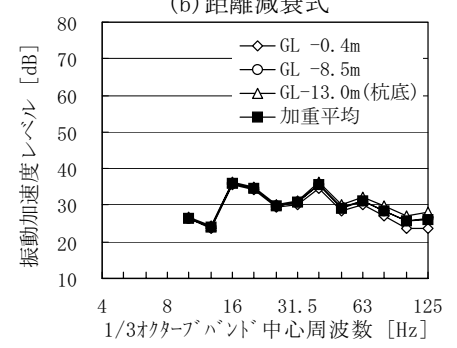

図 18 地中部の振動加速度レベル（ケース B ） 
場合でも実測結果との対応は概ね良好であった。また、床モデルの 有無による差は、床スラブの振動の影響により $16 \mathrm{~Hz}$ 付近で生じた。

F E Mの場合について、建物 1 階柱脚に対寸る地表面の振動伝搬 量について実測結果との比較を図 17 に示す。解析值のほうが全体的 に $5 \sim 10 \mathrm{~dB}$ 程度小さくなったが、双方の傾向は概ね一致した。

\section{3 B、C建物の振動予測}

A建物と同様に、B、C建物の振動予測結果を以下に示す。 (1) B 建物

B 建物について、簡便法による動的地盤ばねを表 4、F E Mおよ び距離減衰式を用いて求めた建物への入力振動を図 18 に示寸。F E $\mathrm{M}$ では、地表面付近のほうが下層部より振動がやや大きくなったが、 トンネルと杭が離れていることや杭長が短いこともあり、ケース A に対し地中部の振動分布の差は小さくなった。1 基礎当たりの平均 杭体軸剛性 $\left(6.72 \times 10^{5} \mathrm{kN} / \mathrm{m}\right)$ は $\mathrm{A}$ 建物より小さいが、地中部振動分 布の差が小さいことから、杭剛性が入力振動の予測精度に与える影 響は少ないと考える。固有值解析より求めた固有振動数および有効 質量比を表 5、入力振動に対する 1 階柱脚の応答倍率を図 19 に示す。 質点系モデル（床モデルあり）の上下 1 次固有振動数はA建物より やや大きく $11.9 \mathrm{~Hz}$ であった。予測した 1 階柱脚における振動加速度 レベルと実測結果の比較を図 20 に示寸。 $50 \mathrm{~Hz}$ 以上は暗振動に近い ため正確な比較はできないが、全体的に解析值のほうが実測值より やや大きくなったが、傾向は概ね一致した。

(2) C建物

C 建物について、簡便法による動的地盤ばねを表 5、F E Mを用 いて求めた建物への入力振動を図 21 に示す。B 建物と同様に杭長が 短いため、地中部の振動分布の差は小さかったが、土被りが小さい こともあり地表面付近のほうが杭底位置より振動がやや大きくなっ た。 1 基礎当たりの平均杭体軸剛性 $\left(1.38 \times 10^{6} \mathrm{kN} / \mathrm{m}\right)$ は $\mathrm{A}$ 建物と同 程度である。固有值解析より求めた固有振動数および有効質量比を 表 7、入力振動に対する 1 階柱脚の応答倍率を図 22 に示す。質点系 モデル（床モデルあり）の上下 1 次固有振動数は $13.1 \mathrm{~Hz}$ であった。 予測した 1 階柱脚における振動加速度レベルと実測結果の比較を図 23 に示す。 $20 \mathrm{~Hz}$ 以上は暗振動に近いため正確な比較はできないが、

6.3〜 $16 \mathrm{~Hz}$ では、双方の傾向は概小対応した。

\section{4 予測精度}

$\mathrm{A} 、 \mathrm{~B} 、 \mathrm{C}$ 建物について、1 階柱脚における予測值と実測值を周 波数帯ごとに比較した結果を図 24 に示す。各建物とも予測值は、入 力振動を FEM により求め、床スラブを考慮した質点系モデルで応 答倍率を求めた場合の結果である。予測結果と実測結果の差は概ね 5〜10dB の範囲であり、予測結果のほうが実測結果より全体的に大 きくなった。ケース B では実測結果との差がやや大きくなったが、 土被りが大きいため地盤物性の設定の誤差が影響した可能性がある。

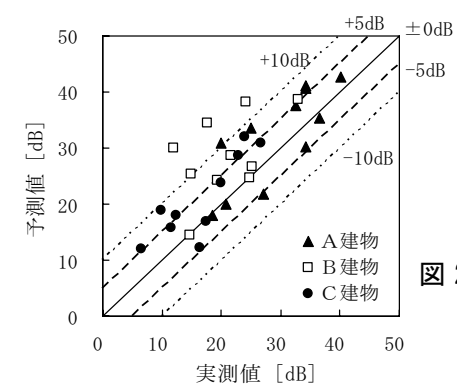

図 24 階柱脚の振動加速度 レベルの予測值と実測值比較 (ケース A, B, C)
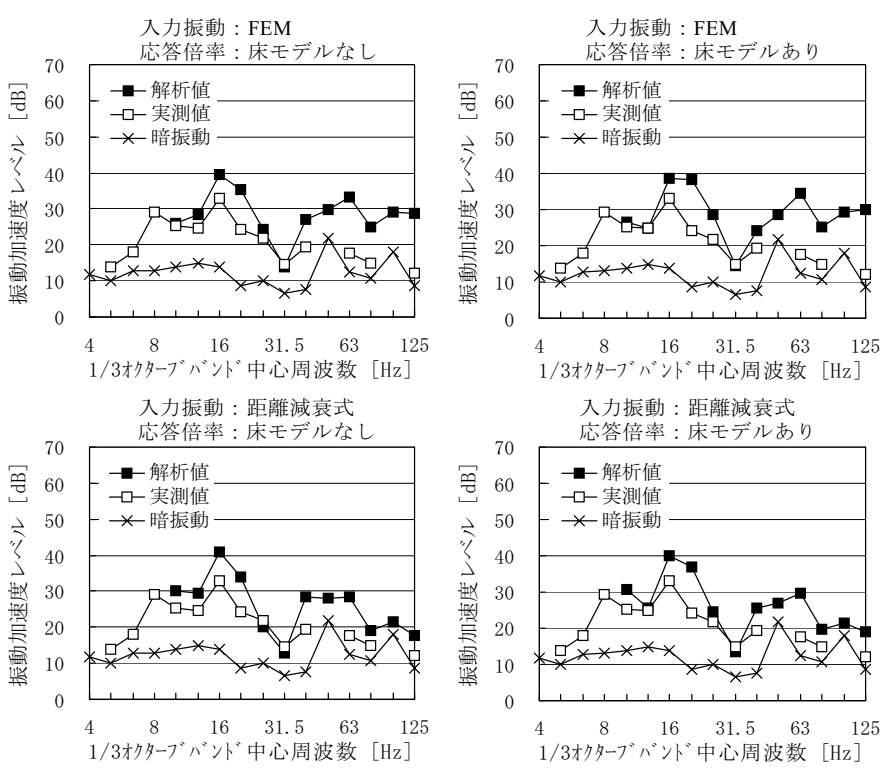

図 201 階柱脚における振動予測結果と実測結果の比較（ケースB）

表 6 地盤ばね定数と比率（ケースC）

\begin{tabular}{|l|c|c|}
\hline \multicolumn{1}{|c|}{ 部位 } & $\begin{array}{c}\text { 地盤ばね定数 }{ }^{*} \\
(\mathrm{kN} / \mathrm{m})\end{array}$ & 比率 \\
\hline パイルキャップ ${ }^{* 2}$ & $1.67 \times 10^{5}$ & 0.089 \\
\hline 杭周(GL-2.0〜-6.5m) & $7.44 \times 10^{4}$ & 0.040 \\
\hline 杭周(-6.5〜-9.3m) & $1.54 \times 10^{5}$ & 0.082 \\
\hline 杭周(-9.3〜-15.0m) & $1.19 \times 10^{6}$ & 0.633 \\
\hline 杭底 & $2.93 \times 10^{5}$ & 0.156 \\
\hline 合計 & $1.88 \times 10^{6}$ & 1.0 \\
\hline
\end{tabular}

*1：1 基礎当たり（杭 3 本分）の值

*2 : 底面（杭で囲まれた範囲を除く）のみ考慮
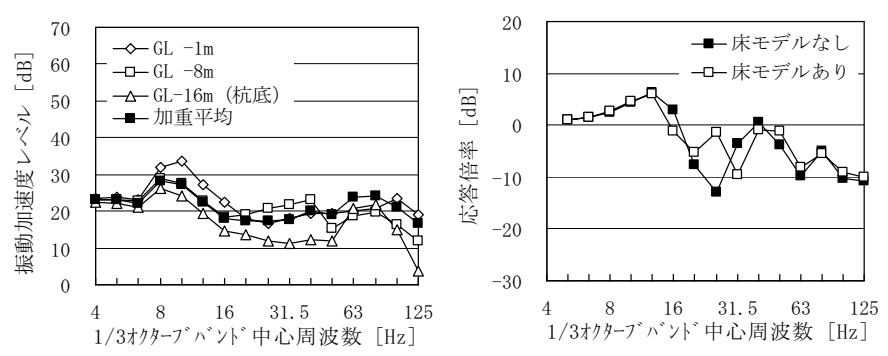

図 21 地中部の振動加速度

図 22 入力振動に対する 1 階柱脚 レベル (ケースC $)$

の応答倍率 (ケースC)

表 7 固有振動数（ケース C ） [Hz]

\begin{tabular}{|l|c|c|c|c|}
\hline & 1 次 & 2 次 & 3 次 & 4 次 \\
\hline 床モデルなし & 13.8 & 41.1 & 74.7 & - \\
& $(0.962)$ & $(0.036)$ & $(0.002)$ & - \\
\hline 床モデルあり & 13.1 & 20.2 & 24.1 & 45.7 \\
& $(0.903)$ & $(0.008)$ & $(0.060)$ & $(0.026)$ \\
\hline
\end{tabular}

( ) 内は有効質量比
入力振動 : FEM 応答倍率 : 床モデルなし

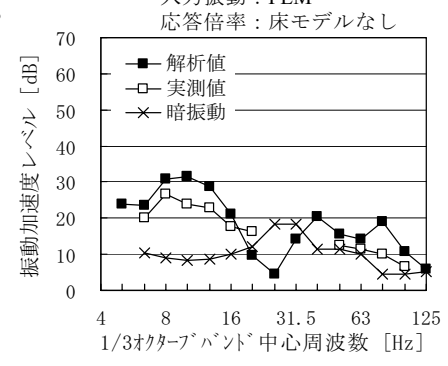

和“中周波数 $[\mathrm{Hz}]$ 


\section{4.まとめ}

鉄道トンネルに近接する 3 地点の杭基礎を有する実大建物を対象 として列車振動（上下振動）の伝搬性状を実測により把握するとと もに、既報 ${ }^{13)}$ で示した模型実験に基づく振動伝搬予測手法を実大建 物へ適用し、実測結果と比較することにより以下の知見が得られた。 (1) 入力の相互作用として杭の地盤ばね定数の比率で加重平均した 地中部振動を入力振動とし、慣性の相互作用として地盤ばねを取り 付けた上部構造モデルの応答倍率を考慮することにより、実大建物 においてもトンネルから建物基礎への振動伝搬を概ね予測できる。 （2）トンネル、地盤、建物等の条件が異なる 3 地点の予測結果は、 実測結果に対し 5〜10dB 程度の差であった。予測結果の誤差の主な 原因として考えられる杭の軸剛性等に起因寸る入力振動および杭の 地盤ばねに起因する応答倍率について検討し、予測精度に与える影 響を把握した。

(3) シールドトンネルでは、地中部の振動を距離減衰式で求めた場 合でも予測精度は概ね確保できることから、本手法は、F E M 等の 煩雑な数值解析を用いずに地盤と建物の動的相互作用を考慮できる 実用的な振動伝搬予測手法として有効である。

本振動予測ではトンネル内の振動が既知であることを前提とした が、地表面の振動のみ既知である場合でも、地中部の振動を F E M 等で推定可能なため、本手法を適用できる。今後、トンネル以外に 盛土や高架橋を列車が走行する場合についても検討していきたい。

\section{謝辞}

本研究における振動測定では、東京都の古田勝氏、鉄道総研の津 野究氏の協力を得ました。ここに記して感謝の意を表します。

\section{参考文献}

1) 国土交通省ほか編：2001 年版 限界耐力計算法の計算例とその解説，工学 図書, 2001

2) 山原浩 : 環境保全のための防振設計，彰国社，1974

3) 野口祐司, 武居泰ほか 4 名：駅複合建物の鉄道振動伝搬特性 その 1 工 事進捗に伴う地盤・基礎の振動特性, 日本建築学会大会学術講演梗概集, D-1, pp.151-152, 2002

4) 深沢尚宏, 北村春幸, 藤田隆史, 浅野美次ほか 2 名: 敷地地盤の微振動調 查に基づく免震建物の微振動応答予測手法, 日本建築学会技術報告集, 第 19 号, pp.73-78, 2004

5) 高木正美, 藤井俊二, 曽田五月也 : 建物防振構法の効果に関する実験的, 解析的研究, 日本建築学会構造系論文集, 第 541 号, pp.105-112, 2001

6) 藤井光治郎, 蓮田常雄ほか 1 名: 線路上空建物の振動騒音予測に関寸る研 究 その 3 振動・騒音予測法と建物一の振動入力評価, 日本建築学会大 会学術講演梗概集, D-1, pp.1535-1536, 1994

7) 田中靖彦, 富澤稔ほか 2 名 : 交通振動を受ける $\mathrm{S}$ 造建物の環境振動予測手 法, 日本建築学会構造系論文集, 第 470 号, pp.151-158, 1995

8) K.H.Chua, K.W.Lo, T.Balendra: Building Response due to Subway Train Traffic, Journal of Geotechnical Engineering, pp.747-754, 1995.11

9) 武居泰, 蓮田常雄ほか 2 名: 線路上空建物の振動騒音予測に関する研究 そ の 52 次元 FEM による振動解析, 日本建築学会大会学術講演梗概集, D-1, pp.1539-1540, 1994

10) 武居泰, 藤井光治郎ほか 2 名: 開削トンネルから地盤・建物への列車振 動伝搬性状，鉄道技術連合シンポジウム(J-RAIL2005), pp.553-556, 2006

11）高野真一郎, 佐々木文夫 : 基礎の剛性を考慮した群杭基礎の動剛性と入 力損失効果 その 2, 日本建築学会大会学術講演梗概集, D-1, pp.201-202, 2006

12) 日本建築学会編 : 入門・建物と地盤との動的相互作用, 1996

13) 武居泰, 中井正一ほか 2 名 : トンネルー地盤一架構系模型を用いた振動 伝搬特性に関する研究, 日本建築学会環境系論文集, 第 616 号, pp.17-24, 2007

14) 田治米辰雄ほか 2 名 : 地盤と震害, 䬱書店, 1978

15) 木村和夫, 鈴木健司ほか 4 名：コイルばね防振軌道の設計と施工, 鉄道
技術連合シンポジウム(J-RAIL2000)，pp.47-50，2000

16）古田勝、長嶋文雄：地下鉄走行に伴うシールドトンネル及び地盤系の動 的応答解析とその計算例, トンネル工学研究発表会論文・報告集, 第 4 巻, pp.93-100, 1994

17) 日本建築学会編 : 建物と地盤の動的相互作用を考慮した応答解析と耐震 設計, 日本建築学会, 2006

18）小堀鐸二ほか 3 名: 長方形基礎の Dynamic Ground Compliance その 1 半無限弾性地盤上の場合, 京都大学防災研究所年報, 第 10 号 A, pp.283-314, 1967

19) 藤井光治郎, 武居泰ほか 4 名 : 地下鉄道近接建物の振動伝搬予測に関寸 る研究 その 22 次元有限要素法によるトンネル函体一地盤系振動解析, 日本建築学会大会学術講演梗概集, D-1, pp.247-248, 2004

20) 津野究, 古田勝ほか 3 名: 地下鉄シールドトンネルから伝播する広帯域 振動の減衰特性, 土木学会論文集, No.792/III-71, pp.185-197, 2005

21) 加藤泰正, 本間俊雄 : 環境振動に関する床スラブ設計支援システムの開 発，日本建築学会技術報告集，第 7 号, pp.169-174, 1999

22)古田勝、長嶋文雄 : 地下鉄シールドトンネルの振動調查と解析例, トンネ ル工学研究発表会論文・報告集、第 1 巻, pp.101-106, 1991

\section{付録 1 簡便法による杭の動的地盤ばねの算定}

文献 17)を参考に、杭の上下地盤ばねを下式から求めている。

・杭周地盤ば悋定数（単位長さ当たり）：

$$
S_{v}=2 \pi G_{e} / \log _{e}\left(2 r_{m} / B\right) \quad r_{m}=2.5 L\left(1-v_{e}\right)
$$

$B$ : 杭径 $L$ : 工学的基盤までの杭長 $G_{e}$ : 表層地盤の平均せん断岡性

$v_{e}:$ 表層地盤の平均ポアソン比

・杭先端地盤壮站定数 : $k_{b}=\frac{3 \pi}{8} \frac{\pi G_{b} B}{2\left(1-v_{b}\right)}$

$G_{b}$ : 支持層のせん断岡性 $v_{b}$ : 支持層のポアソン比

·地盤ぼ站定数(全体) $K_{V S}=E_{p} A \beta_{s} \frac{E_{p} A \beta_{s}\left(1-e^{-2 \beta_{s} L}\right)+k_{b}\left(1+e^{-2 \beta_{s} L}\right)}{E_{p} A \beta_{s}\left(1+e^{-2 \beta_{s} L}\right)+k_{b}\left(1-e^{-2 \beta_{s} L}\right)}$

$\beta_{\mathrm{s}}^{2}=S_{V} / E_{p} A \quad E_{p}$ : 杭のヤング係数 $\quad A$ : 杭の断面積

- 隇衰保数: $C_{S}=h_{V S 1} K_{V S} /(\pi f)+C_{V S 2}\left(f-f_{g}\right) / f \quad C_{V S 2}=\rho_{b} V_{L a b} \pi \mathrm{r}_{V 0}{ }^{2}$ $h_{v s l}$ : 支持層の減衰定数 $f_{g}$ : 地盤の 1 次固有振動数 $\left(=V_{s e} / 4 L\right)$

$f:$ 地盤 - 建物連成系の上下 1 次固有振動数

$V_{L a b}:$ 支持層の L ysmer の波動速度 $\left(=3.4 V_{s b} /\left\{\pi\left(1-\nu_{b}\right)\right\}\right)$

$r_{V 0}:$ ばね袮定用の等価基礎半径

付録 2 地盤振動の距離減衰式

文献 20)を参考に、地中部の振動の減衰特性を下式より求める。

$$
L_{V A}(f)-L_{V A 0}(f)=-A \cdot \log _{e}\left(R / R_{0}\right)
$$

$L_{V A}(f)$ : 地中部に拝胡 $1 / 3$ オクターブバンド分析による中心周波数 $f(\mathrm{~Hz})$ の振 動加速度レベル(dB)

$L_{V A d}(f)$ ：トンネル側壁（アーチ部半径方向）の $1 / 3$ オクターブバンド分析によ る中心周波数 $f(\mathrm{~Hz})$ の振動加速度レベル $(\mathrm{dB})$

$R:$ 振動が地盤内を伝播する距離 $(\mathrm{m})$ (付図 1 参照)

$R_{\theta}:$ 振動源から基準点の距離 ( $1 \mathrm{~m}$ と仮定)

$A:$ 減衰汇関する保数

減衰に関する係数 $A$ と周波数の関係を付図 2 に示す。文献 20 )では、地表 面振動を対象として回帰式 $(A=0.15 f)$ を提案している。地中部振動の場合、 実測值と比較すると $16 \sim 50 \mathrm{~Hz}$ で実測值のほうがやや大きくなったが、傾向 は概䄈一致するため、本予測では地表面振動に対する式を準用する。なお、 アーチ部では、円周方向と半径方向で振動性状が類似していることや測定結 果にばらつきが少ないこと等の理由から、基準とする振動 $\left(L_{V A t}\right)$ をアーチ部 半径方向としている ${ }^{22)}$ 。

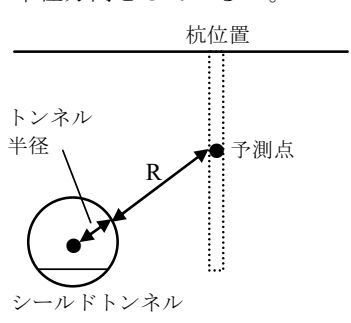

付図 1 振動伝播距離（R）

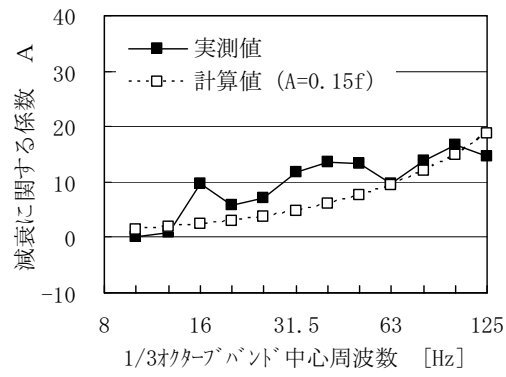

付図 2 倸数 $\mathrm{A}$ と周波数の関係
(2007年 9 月 10 日原稿受理, 2008 年 1 月 23 日採用決定) 